\title{
Gender differences in cadmium and cotinine levels in prepubertal children
}

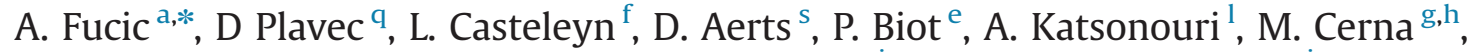
L.E. Knudsen ${ }^{\circ}$, A. Castano ${ }^{\text {c }}$, P. Rudnai ${ }^{\mathrm{p}}$, A. Gutleb $^{\mathrm{j}}$, D. Ligocka ${ }^{\mathrm{n}}$, I-R. Lupsa ${ }^{\mathrm{i}}$, M. Berglund ${ }^{\mathrm{d}}$, M. Horvat ${ }^{\mathrm{m}}$, K. Halzlova ${ }^{\text {k,l }}$, G. Schoeters ${ }^{v}$, G. Koppen ${ }^{\text {v }}$, A. Hadjipanayis ${ }^{\mathrm{x}}$, A. Krskova ${ }^{\text {g,h }}$, S. Középesy ${ }^{p}$, M. Arendt ${ }^{\mathrm{b}}$, M.E. Fischer ${ }^{\text {g,h }}{ }^{\text {, B. Janasik }}{ }^{\mathrm{n}}$, A.E. Gurzau ${ }^{\mathrm{i}}$, E.S. Gurzau ${ }^{\mathrm{i}}$, M. Grandér ${ }^{d}$, K. Larsson ${ }^{\text {d, M. Jajcaj }}{ }^{\mathrm{m}}$, M. Kolossa-Gehring ${ }^{\mathrm{t}}$, O. Sepai ${ }^{\mathrm{u}}$, K. Exley ${ }^{\mathrm{u}}$, M. Bartolome ${ }^{c}$, F. Cutanda ${ }^{c}$, D. Mazej ${ }^{\mathrm{m}}$, J.K.S. Nielsen ${ }^{ }$, J. Snoj-Tratnik ${ }^{\mathrm{m}}$, G. Schwedler ${ }^{\mathrm{t}}$, U. Fiddicke ${ }^{t}$, M. Seiwert ${ }^{t}$, E. Govarts ${ }^{\text {v }}$, E. Den Hond ${ }^{\text {v }}$, H.M. Koch ${ }^{\text {w }}$, A. Lopez ${ }^{\text {, }}$,

A. Joas ${ }^{r}$, R. Joas ${ }^{\mathrm{r}}$

a Institute for Medical Research and Occupational Health, Ksaverska c 2, 10000 Zagreb, Croatia

${ }^{\mathrm{b}}$ Initiativ Liewensufank, Luxembourg

${ }^{\mathrm{C}}$ Instituto de Salud Carlos III, Spain

d Institute of Environmental Medicine, Karolinska Institutet, Sweden

e DG Environment, Multilateral and Strategic Affairs, Belgium

${ }^{\mathrm{f}} \mathrm{KU}$ Leuven, Belgium

${ }^{g}$ Laboratoire National de Sante, Luxembourg

h National Institute of Public Health, Czech Republic

${ }^{\mathrm{i}}$ Environmental Health Center, Romania

j Centre de Recherche Public - Gabriel Lippmann, Luxembourg

${ }^{\mathrm{k}}$ Public Health Authority, Slovak Republic

${ }^{1}$ State General Laboratory, Ministry of Health, Cyprus

${ }^{\mathrm{m}}$ Institute Josef Stefan, Slovenia

${ }^{\mathrm{n}}$ Nofer Institute of Occupational Medicine, Poland

${ }^{\circ}$ University of Copenhagen, Denmark

${ }^{\mathrm{p}}$ National Institute of Environmental Health, Hungary

${ }^{\mathrm{q}}$ Children Hospital Srebrnjak, Croatia

r BiPRO GmbH, Germany

${ }^{\mathrm{s}}$ Federal Public Service Health, Food Chain Safety and Environment - DG Environment, Belgium

${ }^{\mathrm{t}}$ Federal Environment Agency (UBA), Germany

u Public Health England, UK

${ }^{v}$ Flemish Institute for Technological Research (VITO), Environmental Risk and Health, Netherlands

${ }^{\mathrm{w}}$ Institute for Prevention and Occupational Medicine of the German Social Accident Insurance - Institute of the Ruhr-Universität Bochum (IPA), Germany

${ }^{x}$ Larnaca General Hospital, Ministry of Health, Republic of Cyprus

\section{A R T I C L E I N F O}

\section{Article history:}

Received 24 May 2014

Received in revised form

27 August 2014

Accepted 1 October 2014

\begin{abstract}
A B S T R A C T
Susceptibility to environmental stressors has been described for fetal and early childhood development. However, the possible susceptibility of the prepubertal period, characterized by the orchestration of the organism towards sexual maturation and adulthood has been poorly investigated and exposure data are scarce. In the current study levels of cadmium (Cd), cotinine and creatinine in urine were analyzed in a subsample 216 children from 12 European countries within the DEMOCOPHES project. The children were divided into six age-sex groups: boys (6-8 years, 9-10 years and 11 years old), and girls (6-7 years, 8-9 years, 10-11 years). The number of subjects per group was between 23 and 53 . The cut off values were set at $0.1 \mu \mathrm{g} / \mathrm{L}$ for $\mathrm{Cd}$, and $0.8 \mu \mathrm{g} / \mathrm{L}$ for cotinine defined according to the highest limit of quantification. The levels of $\mathrm{Cd}$ and cotinine were adjusted for creatinine level. In the total subsample group, the median level of $\mathrm{Cd}$ was $0.180 \mu \mathrm{g} / \mathrm{L}$ (range $0.10-0.69 \mu \mathrm{g} / \mathrm{L}$ ), and for cotinine the median wet weight value was $1.50 \mu \mathrm{g} / \mathrm{L}$ (range $0.80-39.91 \mu \mathrm{g} / \mathrm{L}$ ). There was no significant difference in creatinine and cotinine levels between genders and age groups. There was a significant correlation between levels of cadmium and
\end{abstract}

\footnotetext{
* Corresponding author. Fax: +38514673303.

E-mail address: afucic@imi.hr (A. Fucic).
} 
creatinine in all children of both genders. This shows that even at such low levels the possible effect of cadmium on kidney function was present and measurable. An increase in Cd levels was evident with age. Cadmium levels were significantly different between $6-7$ year old girls, 11 year old boys and $10-11$ year old girls. As there was a balanced distribution in the number of subjects from countries included in the study, bias due to data clustering was not probable. The impact of low Cd levels on kidney function and gender differences in $\mathrm{Cd}$ levels needs further investigation.

(c) 2014 Elsevier Inc. All rights reserved.

\section{Introduction}

Prepuberty and puberty are critical periods of maturation during which hormones orchestrate the development of secondary sexual characteristics, skeleton and behavior. Estrogen and testosterone levels during these periods may be disturbed by environmental stressors from air, water, and food. A large number of xenobiotics/xenoestrogens couple estrogen receptors at different efficiency, thus redirecting biological pathways of maturation. The fact that some agents such as cotinine and fungicides act as aromatase inhibitors by lowering levels of estrogen and increasing levels of testosterone (Barbieri et al., 1986; Trosken et al., 2006) has not been investigated to the same extent. The currently reported increased incidence of early maturation or delay in onset of puberty in industrialized countries may have been related to environmental settings contaminated with hormonally active agents (Jacobson-Dicman and Lee, 2009). Additionally, exposure to endocrine disruptors during prepuberty may have significant implications on health risks during adulthood such as an increase in sterility of both genders, as well as increased incidence of testicular cancer and higher incidence of breast cancer in younger age groups (Znaor et al., 2013; Giannandrea et al., 2013; Toppari and Juul, 2010; Fucic et al., 2012).

Estrogen is defined as an endocrine and paracrine agent and neuromodulator that acts via three receptors so far known. By interacting with receptors xenoestrogens may have broad biological effects on the human organism. The impact of endocrine active agents on carcinogenesis is of great significance as according to current knowledge all cancers are accompanied by disturbances in estrogen receptor distribution and/or estrogen and aromatase levels (Fucic et al., 2012; Fucic et al., 2010; Yakimchuk et al., 2012; Okitsu et al., 2010; Kim et al., 2013). However, xenoestrogenic effects are not limited to carcinogenesis since other systems like the cardiovascular system and the urinary system are also modulated by estrogen (Hagenfeldt and Eriksson, 1988; Robinson et al., 2013). Also, disturbances of androgen receptors and testosterone levels are related with for example breast, lung and prostate cancer (Thike et al., 2014; Chang et al., 2013).

Cadmium is one of the most common endocrine disruptors in a child's living environment which may be present in food and air (due to environmental tobacco smoke, ETS) (Satarug and Moore, 2004, Watanabe et al., 2013). Rice is the most frequent dietary source of Cd (Kipppler et al., 2012). Furthermore, the dietary intake of toxic metals including Cd may be higher in children than in adults (Liu et al., 2010).

Cadmium is a well-known toxic metal that binds to estrogen receptors (metalloestrogen) (Crespo-Lopez et al., 2009; Buzard and Kasprzak, 2000; Byrne et al., 2013; Darbre, 2006; Nasiadek et al., 2011). This toxic metal may cause different neurotoxic effects, but also inflammation which is associated with Cd-related cardiovascular diseases and oxidative stress (Colacino et al., 2014).

The benchmark dose for $\mathrm{Cd}$ in adults for renal effects has been calculated to be $0.6-1.1 \mu \mathrm{g} / \mathrm{g}$ creatinine (Suwazono et al., 2006). A recent study in children showed that exposures even below the reference level for Cd based on renal effects, set by the European
Food Safety Authority to $1 \mu \mathrm{g} / \mathrm{g}$ creatinine and to $5.24 \mu \mathrm{g} / \mathrm{g}$ creatinine by to the World Health Organization, still cause learning disabilities (Ciesielski et al. 2012). In an adult population of Swedish women tubular and glomerular effects in the kidney were already significantly increased at mean levels of $0.8 \mu \mathrm{g} / \mathrm{g}$ creatinine (Akesson, et al., 2005). A long term study conducted in Japan suggested irreversible and slowly progressive renal tubular dysfunction after exsposure to environmental $\mathrm{Cd}$ even after reduction of exposure (Iwata et al., 1993). Additionally, Cd exposure has been associated with a decrease of estradiol levels (Zhang et al., 2008). The specific susceptibility of the prepubertal period for toxic metals has been shown in an animal model, where exposure to lead until puberty caused higher renal toxicity than exposure during adulthood (Berrahal et al., 2011).

Metallothioneines (MT) are metal binding proteins present in humans in four isoforms and regulated by hormones. The complex of Cd and MT is nephrotoxic (Klaassen et al., 2009) and its bioaccumulation during prepuberty and puberty, as well as its specific gender related susceptibility, has not yet been investigated.

Apart from Cd, nicotine is another common pollutant present in the life environment of children, and potentially has an impact on the developing hormone system. Environmental tobacco smoke has mainly been known to be associated with an increased incidence of asthma, wheezing illnesses, bronchiolitis and cognitive abilities even at very low levels (Hwang et al., 2012; Tung et al., 2013; Yolton et al., 2005). Despite global efforts for reducing the number of smokers, children are not protected as they are predominantly exposed at home. Cigarette smoke is a source of both chemical agents and radiation (polonium). Cotinine, a metabolite of nicotine, is a commonly used biomarker of exposure to tobacco smoke. However, cotinine is also an active molecule that can have impact on human health via several mechanisms. Additionally to aromatase inhibition (an anti-estrogen activity) (Barbieri et al., 1986; Kadohama et al., 1993; Myong et al., 2013; Soldin et al., 2011; Zeller and Berger, 1989), cotinine is mitogenic for smooth muscle cells at concentrations seen among passive smokers. This represents a potential risk for blood vessel intimal hyperplasia (Calphor et al., 1997). Cotinine has also been shown to be an immunosuppressor in animal models, but whether this effect is a consequence of cotinine or testosterone, which is also known to be immunosuppressive (Furman et al., 2013), is unknown. An increase of testostosterone by aromatase inhibition has not been proven (Kalra et al., 2004). Exposure to ETS decreases levels of estradiol in women (Soldin et al., 2011).

The prepubertal period may be a vestibule for puberty and thus crucial in the final physiological preparation for puberty, which therefore makes it specifically vulnerable to the environmental contaminants (Mantovani and Fucic, 2014). The possible impact of hormonally active agents from the living environment on the prepubertal period has still not been investigated.

The COPHES and DEMOCOPHES twin projects, which represent the first European harmonized biomonitoring study on children and their mothers in 17 countries, included measurements of urinary cadmium (Cd) and cotinine. Children were the primary target group of the study because the EU Environment and Health 
Action Strategy (SCALE) was focused on children for their particular and universally recognized vulnerability (Becker et al., 2014; Den Hond et al., 2014; Casteleyn et al., this issue).

The aim of the current study was to investigate possible age and gender differences in levels of $\mathrm{Cd}$ and cotinine between the prepubertal period defined as age 6-7 and 6-8 years for girls and boys, respectively (Berberoglu, 2009; Golub et al., 2008) and the early pubertal period. In the study a subample of COPHES/DEMOCOHES cohort was analyzed. As this is the first study to compare the possible biological effects of $\mathrm{Cd}$ and cotinine during the prepubertal and early pubertal period, it was not possible to refer to any already agreed criterion in regard to the selection of age groups and the investigated biomarkers, thus the age groups were selected arbitrarily taking into account that girls enter puberty before boys.

Although most studies investigate ETS in children using questionnaires it has been shown that the method is unreliable as smokers may not report their smoking habits acurately. Therefore, cotinine levels in urine are a much more objective measurement (Butz et al., 2011). In the current study Cd was measured in urine as a reliable biomarker of exposure (Trzcinka-Ochocka et al., 2004). As increased creatinine clearance has recently been shown to be a good indicator of tubular damage in populations environmentally exposed to Cd (Kobayashi et al., 2008) a correlation analysis of $\mathrm{Cd}$ and creatinine was performed. Additionally, impact of Cd on levels of creatinine was investigated and compared between selected gender and age groups.

\section{Subjects and methods}

\subsection{Population}

The DEMOCOPHES study protocol of the EU Life + project was approved by the ethical committee of each European country included. Participants or their respective mothers (depending on age) gave their informed consent. In the current study results of the analysis of chidren from Slovenia, Spain, Belgium, Denmark, Luxemburg, Czech Republic, Cyprus, Sweden, Romania, Poland, Slovakia and Hungary were included. In these countries the levels of $\mathrm{Cd}$ and cotinine were higher than the mean values of $\mathrm{Cd}$ and cotinine in all countries included in the DEMOCOPHES project. The selection of subsample of the analyzed children population based on Cd and cotinine levels as described in Methods consisted of 216 children (117 boys and 99 girls). All of the subjects in the listed countries within the age range of 6-11 years were analyzed. Approximately 3 subjects per age/sex group for each country were analyzed.

Children were recruited in schools between 2011 and 2012 and had to be living at the same location for at least the five previous years. Children living in hospitals or institutions, being homeless, or presenting metabolic disturbances or abnormal urine excretion were excluded.

For the purpose of the study children were divided into 6 "agesex" groups: boys $6-8$ years $(n=53)$, girls $6-7$ years $(n=30)$, boys $9-10$ years $(n=41)$, girls $8-9$ years $(n=32)$, boys 11 years $(n=23)$, and girls $10-11$ years $(n=37)$.

Mothers were provided with materials for urine collection. The first morning urine was collected in a $250 \mathrm{~mL}$ polypropylene vessel previously rinsed with $10 \% \mathrm{HNO}_{3}$ to avoid contamination (from the material). Urine samples, initially kept at $4{ }^{\circ} \mathrm{C}$, were aliquoted and stored at $-20^{\circ} \mathrm{C}$ until analysis.

\section{Methods}

Cadmium, cotinine and creatinine were analyzed in European laboratories that successfully passed the Quality Assurance program established by COPHES. For each parameter, the laboratories used different laboratory procedures but all followed the same procedures for quality assurance and quality control requested by the COPHES Quality Assurance Unit. Each laboratory had standard operating procedures (SOP) (for details, see Schindler et al., 2013). Additionally, two External Quality Assessment Schemes and two Interlaboratory Comparison Investigations were provided by the COPHES Quality Assurance Unit to ensure quality and comparability of results. Each laboratory had standard operating procedures(SOP). To guarantee comparability and quality of chemical analysis, quality assurance program was designed by COPHES/DEMOCOPHES. The laboratories could use which analytical method they choose but only laboratories that successfully completed the COPHES/DEMOCOPHES quality assurance program were qualified to analyze the samples from the study. Detailes of quality assessment are avaliable in Schindler et al. (2013) Children with levels lower than $0.1 \mu \mathrm{g} / \mathrm{L}$ for $\mathrm{Cd}$, and $0.8 \mu \mathrm{g} / \mathrm{L}$ for cotinine were excluded (levels falling below the highest limits of quantification).

\section{Statistical analysis}

Statistical analysis was performed using StatSoft, Inc. (2011). STATISTICA, version 10 (StatSoft, Inc. Tulsa, OK, USA). Basic descriptive summaries of data were obtained using mean, standard deviation (SD), median, interquartile range (IQR) and range. Differences between groups were calculated using Student's $t$-test or Mann-Whitney $U$-test for gender differences and analysis of variance (ANOVA) or Kruskal-Wallis ANOVA for gender-age groups (for respectively normal and non-normal distributed results). Associations between variables were tested using Spearman's rank order correlations. $P<0.05$ was considered statistically significant for all analyzes.

\section{Results}

Results for Cd and cotinine levels and creatinine were available for 216 children (117 boys and 99 girls aged 6-11 years). Levels of $\mathrm{Cd}$ and cotinine were also adjusted for creatinine level. Data showing levels of $\mathrm{Cd}$, cotinine, creatinine and adjusted levels of $\mathrm{Cd}$ and cotinine for the levels of creatinine are presented in Table 1.

Levels of Cd were in the range of $0.10-0.69 \mu \mathrm{g} / \mathrm{L}$ of urine with a mean (SD) of $0.20 \mu \mathrm{g} / \mathrm{L}(0.104)$. No significant difference was observed between boys and girls for levels of $C d(t=0.585, P=0.559$, Student's t-test) or for Cd/creatinine $(Z=0.096$; $P=0.923$, MannWhitney $U$ test). A significant difference in the levels of $C d$ through "age-sex" groups was found $(H=16.824, P=0.005$, Kruskal-Wallis ANOVA) with the lowest median values in youngest groups and highest values in the oldest groups (significantly different between girls $6-7$ years old and 11 years old boys, $P=0.038$; and between girls 6-7 years old and $10-11$ years old girls, $P=0.024$; Graph 1 ), but no significant difference was found for $\mathrm{Cd} / \mathrm{creatinine}(\mu \mathrm{g} / \mathrm{g})$ values between "age-sex" groups $(F=0.869, P=0.503$, ANOVA). This is most probably due to the significant association between $\mathrm{Cd}$ and creatinine levels $(R=0.420, P<0.001$, Spearman's rank order correlation, (Graph 2). The same level of association could be followed through all "age-sex" groups $(R=0.335-0.617)$ and was comparable in boys $(R=0.387, P<0.001)$ and girls $(R=0.453$, $P<0.001)$. Also a significant difference was found between $\mathrm{Cd}$ levels between subgroups based on the creatinine level $(\leq 1400$ vs. $>1400$ - high creatinine level). A subgroup with high creatinine level had a significantly higher level of $\mathrm{Cd}$ (mean $\pm \mathrm{SD}$; $0.233 \pm 0.106$ vs. $0.179 \pm 0.096 ; t=3.913, P=0.0001)$. 
Table 1

Values of Cd, cotinine and creatinine in each age group according to gender.

\begin{tabular}{|c|c|c|c|c|c|c|c|c|c|c|}
\hline Parameter $\mu \mathrm{g} / \mathrm{L}$ & Gender-age group & $N$ & Mean & SD & Median & Range & & IQR & & Statistics ${ }^{\mathrm{a}}$ \\
\hline \multirow[t]{9}{*}{$\mathrm{Cd}$} & All & 216 & 0.204 & 0.104 & 0.180 & 0.100 & 0.690 & 0.130 & 0.240 & $\mathrm{n} / \mathrm{a}$ \\
\hline & Boys & 117 & 0.208 & 0.107 & 0.180 & 0.100 & 0.640 & 0.130 & 0.240 & $t=0.585 ; P=0.559$ \\
\hline & Girls & 99 & 0.199 & 0.101 & 0.180 & 0.100 & 0.690 & 0.130 & 0.230 & \\
\hline & B6-8 & 53 & 0.190 & 0.112 & 0.160 & 0.100 & 0.640 & 0.120 & 0.220 & $H=16.824 ; P=0.005$ \\
\hline & G6-7 & 30 & 0.157 & 0.055 & 0.150 & 0.100 & 0.360 & 0.120 & 0.200 & \\
\hline & B9-10 & 41 & 0.209 & 0.081 & 0.190 & 0.100 & 0.390 & 0.140 & 0.260 & \\
\hline & G8-9 & 32 & 0.209 & 0.125 & 0.185 & 0.100 & 0.690 & 0.135 & 0.230 & \\
\hline & B11 & 23 & 0.246 & 0.128 & 0.200 & 0.100 & 0.590 & 0.150 & 0.360 & \\
\hline & G10-11 & 37 & 0.225 & 0.097 & 0.210 & 0.100 & 0.550 & 0.150 & 0.290 & \\
\hline \multirow[t]{9}{*}{ Cotinine } & All & 216 & 3.154 & 4.738 & 1.505 & 0.800 & 39.910 & 1.000 & 2.576 & $\mathrm{n} / \mathrm{a}$ \\
\hline & Boys & 117 & 3.037 & 4.264 & 1.500 & 0.800 & 26.400 & 1.000 & 2.500 & $Z=-0.155 ; P=0.877$ \\
\hline & Girls & 99 & 3.294 & 5.263 & 1.600 & 0.800 & 39.910 & 1.000 & 3.310 & \\
\hline & B6-8 & 53 & 2.360 & 2.857 & 1.300 & 0.800 & 15.570 & 0.994 & 2.500 & $H=6.552 ; P=0.256$ \\
\hline & G6-7 & 30 & 2.164 & 1.639 & 1.734 & 0.800 & 7.200 & 1.100 & 2.000 & \\
\hline & B9-10 & 41 & 2.895 & 4.676 & 1.510 & 0.800 & 26.400 & 1.100 & 1.875 & \\
\hline & G8-9 & 32 & 3.366 & 7.047 & 1.214 & 0.800 & 39.910 & 0.900 & 2.429 & \\
\hline & B11 & 23 & 4.849 & 5.678 & 1.900 & 0.800 & 16.770 & 1.100 & 5.679 & \\
\hline & G10-11 & 37 & 4.148 & 5.353 & 1.760 & 0.800 & 20.097 & 1.000 & 4.940 & \\
\hline \multirow[t]{9}{*}{ Creatinine } & All & 216 & 1395.309 & 530.229 & 1351.000 & 341.380 & 3061.027 & 970.000 & 1683.500 & $\mathrm{n} / \mathrm{a}$ \\
\hline & Boys & 117 & 1402.069 & 497.635 & 1362.000 & 460.000 & 2653.795 & 1036.000 & 1724.742 & $t=0.203 ; P=0.839$ \\
\hline & Girls & 99 & 1387.321 & 568.812 & 1335.000 & 341.380 & 3061.027 & 950.000 & 1671.914 & \\
\hline & B6-8 & 53 & 1268.831 & 412.745 & 1183.000 & 585.803 & 2290.000 & 969.000 & 1551.000 & $F=1.808 ; P=0.113$ \\
\hline & G6-7 & 30 & 1262.767 & 465.978 & 1290.000 & 341.380 & 2142.000 & 886.514 & 1508.000 & \\
\hline & B9-10 & 41 & 1488.980 & 534.277 & 1485.643 & 610.000 & 2653.795 & 1080.000 & 1976.206 & \\
\hline & G8-9 & 32 & 1464.635 & 571.336 & 1436.500 & 576.000 & 3001.000 & 1025.000 & 1754.706 & \\
\hline & B11 & 23 & 1554.166 & 550.494 & 1615.158 & 460.000 & 2530.000 & 1191.736 & 1956.000 & \\
\hline & G10-11 & 37 & 1421.444 & 636.653 & 1394.770 & 540.000 & 3061.027 & 950.000 & 1696.000 & \\
\hline \multirow[t]{9}{*}{ Cd/creatinine } & All & 216 & 0.160 & 0.097 & 0.136 & 0.040 & 0.959 & 0.106 & 0.188 & $\mathrm{n} / \mathrm{a}$ \\
\hline & Boys & 117 & 0.163 & 0.111 & 0.137 & 0.040 & 0.959 & 0.108 & 0.180 & $Z=0.096 ; P=0.923$ \\
\hline & Girls & 99 & 0.156 & 0.077 & 0.135 & 0.066 & 0.527 & 0.105 & 0.196 & \\
\hline & B6-8 & 53 & 0.158 & 0.095 & 0.134 & 0.065 & 0.560 & 0.110 & 0.179 & $F=0.869 ; P=0.503$ \\
\hline & G6-7 & 30 & 0.145 & 0.095 & 0.111 & 0.066 & 0.527 & 0.093 & 0.151 & \\
\hline & B9-10 & 41 & 0.152 & 0.065 & 0.141 & 0.040 & 0.312 & 0.111 & 0.175 & \\
\hline & G8-9 & 32 & 0.149 & 0.067 & 0.130 & 0.071 & 0.361 & 0.099 & 0.200 & \\
\hline & B11 & 23 & 0.191 & 0.187 & 0.133 & 0.077 & 0.959 & 0.099 & 0.205 & \\
\hline & G10-11 & 37 & 0.172 & 0.066 & 0.170 & 0.072 & 0.347 & 0.119 & 0.214 & \\
\hline \multirow[t]{9}{*}{ Cotinine/creatinine } & All & 216 & 2.688 & 4.824 & 1.156 & 0.316 & 43.713 & 0.734 & 2.526 & $\mathrm{n} / \mathrm{a}$ \\
\hline & Boys & 117 & 2.539 & 4.297 & 1.138 & 0.316 & 33.000 & 0.755 & 2.168 & $Z=-0.305 ; P=0.761$ \\
\hline & Girls & 99 & 2.865 & 5.399 & 1.254 & 0.359 & 43.713 & 0.680 & 2.833 & \\
\hline & B6-8 & 53 & 2.102 & 2.578 & 1.154 & 0.489 & 12.144 & 0.725 & 2.168 & $H=5.282 ; P=0.383$ \\
\hline & G6-7 & 30 & 1.924 & 1.350 & 1.469 & 0.556 & 5.547 & 0.749 & 2.535 & \\
\hline & B9-10 & 41 & 2.249 & 4.026 & 1.025 & 0.378 & 24.513 & 0.754 & 1.547 & \\
\hline & G8-9 & 32 & 2.910 & 7.618 & 0.963 & 0.473 & 43.713 & 0.609 & 2.083 & \\
\hline & B11 & 23 & 4.061 & 7.008 & 1.526 & 0.316 & 33.000 & 0.886 & 4.329 & \\
\hline & G10-11 & 37 & 3.589 & 5.161 & 1.364 & 0.359 & 25.272 & 0.743 & 3.407 & \\
\hline
\end{tabular}

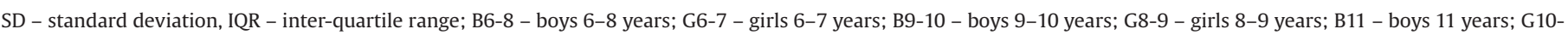
11 - girls 10-11 years of age.

a Statistical analyses were based on Student's $t$-test $(t)$, Mann-Whitney $U$ test $(Z)$, analysis of variance (ANOVA-F), and Kruskal-Wallis ANOVA by ranks $(H)$.

Levels of cotinine were in the range of $0.80-39.91$ with a median (IQR) of 1.505 (1.000-2.576). No significant difference was found between boys and girls for levels of cotinine $(Z=-0.155$, $P=0.877$, Mann-Whitney $U$ test) or for cotinine/creatinine $(Z=-0.305 ; P=0.761$, Mann-Whitney $U$ test). No significant difference in the levels of cotinine through "age-sex" groups was found ( $F=1.808, P=0.113$, ANOVA) although a trend for higher values was found towards the oldest groups. Furthermore, no significant difference was found for cotinine/creatine values between "age-sex" groups $(H=5.282, P=0.383$, Kruskal-Wallis ANOVA) but with lowest median values among groups according to age. Contrary to a significant association seen between $\mathrm{Cd}$ and creatinine, overall no significant association was found between cotinine and creatinine levels $(R=-0.002, P=0.973$, Spearman's rank order correlation, Graph 3).The same level of association could be followed through all "age-sex" groups $(r=0.05-0.15)$ and was comparable in boys $(r=0.04, P=0.656)$ and girls $(r=-0.03$, $P=0.765$ ).

No significant association was found between levels of $\mathrm{Cd}$ and cotinine $(R=0.013, P=0.844)$ but a mild significant association was found for values of $\mathrm{Cd}$ and cotinine when adjusted for creatinine $(R=0.244, P<0.001)$.

\section{Discussion}

During the last decade, a significant progress in the elucidation of the complexity of effects of hormonally active substances from 


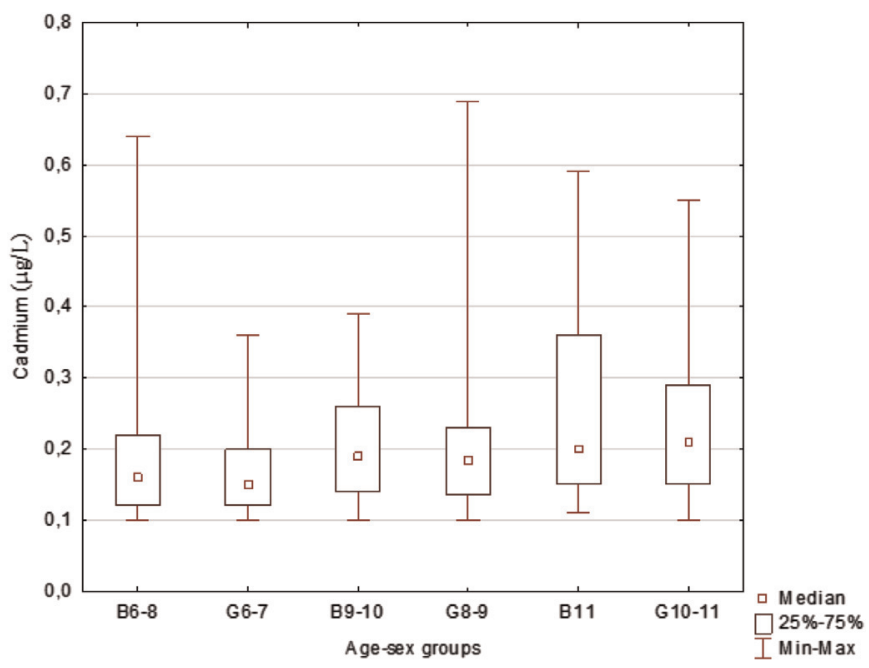

Graph 1. Categorized box and whisker plot of Cd levels $(\mu \mathrm{g} / \mathrm{L})$ in age-sex groups $(N=216)$; B6-8 - boys 6-8 years; G6-7 - girls 6-7 years; B9-10 - boys 9-10 years; G8-9 - girls 8-9 years; B11 - boys 11 years; and G10-11 - girls 10-11 years of age.

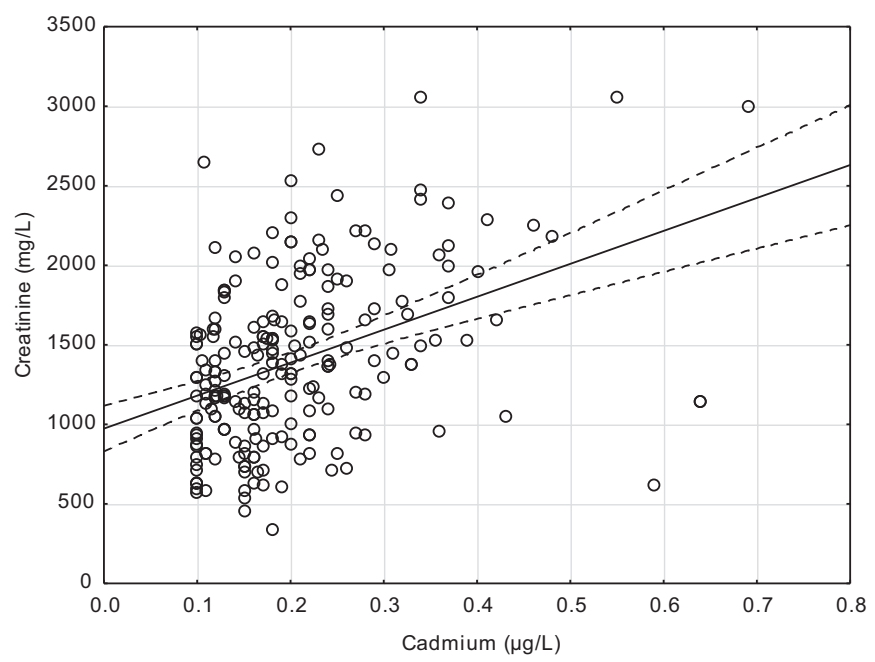

Graph 2. Scatter plot of the association of Cd and creatinine levels $(N=216)$ $r=0.42$, and $P<0.001$. Full line represents the linear correlation equation and dotted lines $95 \%$ confidence intervals.

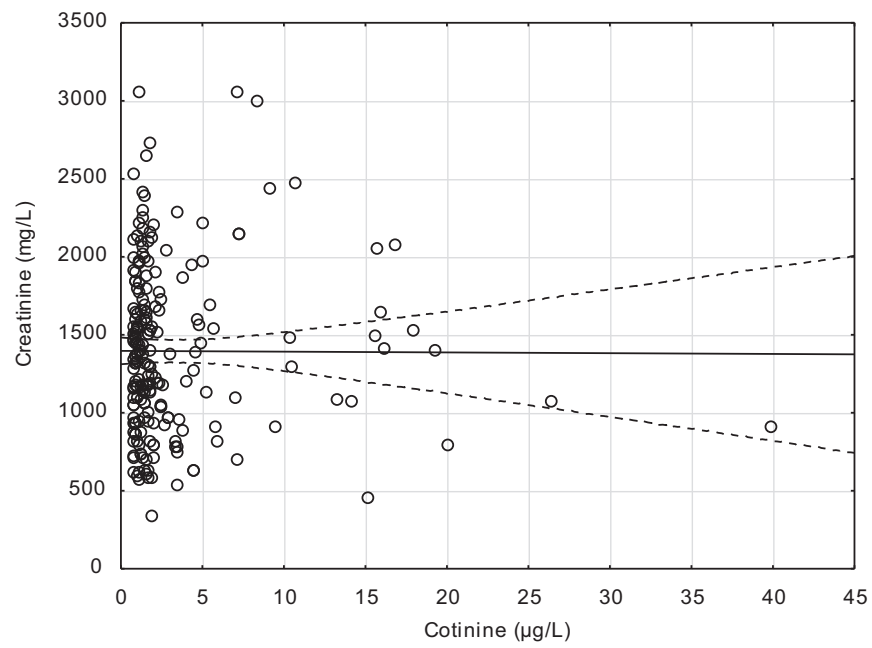

Graph 3. Scatter plot of the association of cotinine and creatinine levels $(N=216)$; $r=-0.002$, and $P=0.973$. Full line represents the linear correlation equation and dotted lines $95 \%$ confidence intervals. the environment has been made. Not only reproductive organs, but also other organ systems, such as cardiovascular and nervous systems are affected and concentrations in humans exceeding effect levels have been measured (Montano et al., 2013). Similarly, in addition to investigations of the transplacental action of environmental agents on fetal development, specific attention is currently focused on puberty as a developmental period in which the balance of estrogen, testosterone and its receptors is of particular importance as a prerequisite of normal maturation. Contrary to recognized gender differences in response to hormonally active agents from the environment during adulthood, a knowledge gap in gender differences of endocrine disruptor impact on development during prepuberty and early puberty exists.

In the current study, data of subsample from the first harmonized European biomonitoring study within the twin projects COPHES and DEMOCOPHES were used in order to investigate possible gender and age differences in levels of $\mathrm{Cd}$ and cotinine during the prepubertal and early pubertal period and their correlation with creatinine levels.

Results showed that overall $\mathrm{Cd}$ and cotinine levels in children aged beteween 6 and 11 year old were similar to those described in previous studies (Cerna et al., 2012; Horton et al., 2013). Levels of $\mathrm{Cd}$ and cotinine increased with age but there was no significant difference within the prepubertal and early pubertal age groups.

The results of the current study showed significantly lower levels of urine-Cd in 6-7 years old girls compared to $10-11$ years old girls and 11 years old boys. Such transient lower levels of urinary Cd may have been correlated with higher testosterone levels in prepubertal girls than in boys and girls during early puberty (Courant et al., 2010; Veldhuis et al., 2001; Belgorosky and Rivarola, 1988) which is in concordance with the earlier onset of puberty in girls. In older age groups, the Cd level in girls increased to that of boys (Graph 1). It could be hypothesized that relatively higher levels of testosterone in girls during this narrow developmental window of prepuberty stimulate metallothionein (MT) synthesis, which causes a more efficient coupling of $\mathrm{Cd}$ as urine levels of $\mathrm{Cd}$ are described to be correlated with MT levels (Kido et al., 1991). This more efficient coupling of Cd in prepubertal girls may furthermore result in higher risks of kidney damage in girls than in boys. Similar mechanisms are present in women who smoke and second hand smokers, where cotinine, as an aromatase inhibitor, causes increased testosterone levels and consequently significantly higher levels of MT (Ronco et al., 2005; Milnerowicz, 1997).

A significant correlation between $\mathrm{Cd}$ and creatinine in our study in all age groups for both genders suggests that even very low levels of Cd may cause disturbances in kidney functions. Significant increase of $\mathrm{Cd}$ levels in children with creatinine levels higher than reference values suggests health risks already at low doses. Cadmium persists in the kidneys of humans for decades and its nephrotoxicity has been reported at low level of exposure (Satarug and Moore, 2004). Thus urinary Cd with levels above $1 \mu \mathrm{g} / \mathrm{L}$ in adults showed increased health risks for albuminuria and chronic kidney disease (Ferrara et al., 2010). Cadmium at low levels exposures can also cause the early onset of diabetic renal complications, osteoporosis, blood pressure problems and increased cancer risk (Nakagawa and NIshio, 1996; Brzoska, 2012; Zhao et al., 2014).

All of the children in this study had levels of cotinine less than $60 \mu \mathrm{g} / \mathrm{L}$ which corresponds to the reported range for non-smoking persons and is similar to levels measured in the US (Butz et al., 2011). There was no difference in cotinine levels between the oldest groups of boys and girls, despite the fact that in this period of life an increase of estrogen and a consequentional acceleration of nicotine metabolism could be expected (Benowitz et al., 2006). There was also no correlation of cotinine with creatinine levels. 
During prepuberty children have the same metabolism and elimination of nicotine as adults (Hukkanen et al., 2005; Leong et al., 1998) but we are yet to investigate whether the same levels of cotinine have different effects on organ systems during puberty maturation. Furthermore the effects of cotinine as an aromatase inhibitor on prepubertal and pubertal development have also not yet been investigated.

Exposure to ETS in children is associated with respiratory diseases such as asthma, respiratory infections and bronchitis (Tung et al., 2013; Hwang et al., 2012). Asthma caused by ETS during puberty is more pronounced in girls (Strong and Chang, 2013). Girls exposed to ETS and allergic sensitization during prepuberty are at greater risk of decreased lung function later in adulthood compared to non-sensitized girls and boys (Brunst et al., 2012). As no gender differences in cotinine levels were detected in our study, it could be hypothesized that cotinine, as an aromatase inhibitor, may have gender related differences in its effects on the respiratory system. The gender differences of incidence and survival in patients with lung cancer is based on differences in estrogen receptor distributions and disturbances and underlines the importance of estrogen in lung tissue (Fucic et al., 2010).

In conclusion, the analysis of $\mathrm{Cd}$ urine levels in 6-11 year old children showed gender differences between 6-7 year old girls, 11 year old boys and 10-11 year old girls which could have been a consequence of increased MT levels stimulated by increased testosterone levels in prepubertal girls. An observed correlation between $\mathrm{Cd}$ levels and creatinine levels suggested an impact on the kidney function even at very low doses. There was no gender or age difference in cotinine levels and correlation with creatinine. All current recommendations of $\mathrm{Cd}$ levels are based on adult populations. There are no data on its specific effects during developmental stages especially during prepuberty and puberty when its xenoestrogenic mechanisms could be expected to have the most impact due to the interaction with increased estrogen and testosterone levels and the specific distribution of ER important for the maturation of all organic systems (Rogol et al., 2002). The possible bias of the current study is its age group selection, as there are no agreed criteria for the definition of age groups with regard to the investigated biomarkers. Thus, the results of this study may serve as initial insight for further studies on susceptibility during prepubertal and early pubertal period. Future research should focus on Cd specific damage of kidney function in prepubertal girls, impact of ETS on osteoporosis in prepubertal and pubertal period and investigation of polycystic ovaria incidence in ETS exposed girls.

\section{Acknowledgment}

We wish to thank the European Commission, DG for Research and Innovation (RTD), which funds COPHES within the 7 Framework Programme (No. 244237). DEMOCOPHES (LIFE09 ENV/BE/000410) received 50\% funding through the LIFE + Financial Instrument of the European Union (DG ENV), and 50\% through funding received from DEMOCOPHES partners (http://www.eu-hbm.info/DEMOCOPHES/ project-partners). More information about the COPHES/DEMOCOPHES twin projects can be found at www.eu-hbm.info and other papers in this special Issue. Finally, we would particularly like to thank all the mothers and children who so generously agreed to participate in this study.

\section{References}

Trösken, E.R., Fischer, K., Völkel, W., Lutz, W.K., 2006. Inhibition of human CYP19 by azoles used as antifungal agents and aromatase inhibitors, using a new LC-MS/
MS method for the analysis of estradiol product formation. Toxicology 219 (13), 33-40.

Akesson, A., Lundh, T., Vahter, M., Bjellerup, P., Lidfeldt, J., Nerbrand, C., Samsioe, G. Strömberg, U., Skerfving, S., 2005. Tubular and glomerular kidney effects in Swedish women with low environmental cadmium exposure. Environ. Health Perspect. 113 (11), 1627-1631.

Barbieri, R.L., Gochberg, J., Ryan, K.J., 1986. Nicotine, cotinine, and anabasine inhibit aromatase in human trophoblast in vitro. J. Clin. Investig. 77, 1727-1733.

Belgorosky, A., Rivarola, M.A., 1988. Progressive increase in nonsex hormonebinding globulin-bound testosterone and estradiol from infancy to late prepuberty in girls. J. Clin. Endocrinol. Metab. 67 (2), 234-237.

Benowitz, N.L., Lessov-Schlaggar, C.N., Swan, G.E., Jacob 3rd, P., 2006. Female sex and oral contraceptive use accelerate nicotine metabolism. Clin. Pharmacol. Ther 79 (5), 480-488.

Berberoglu, M., 2009. Precocious puberty and normal variant puberty: definition, etiology, diagnosis and current management. J. Clin. Res. Pediatr. Endocrinol. 1 (4), 164-174.

Berrahal, A.A., Lasram, M., El Elj, N., Kerkeni, A., Gharbi, N., El-Fazâa, S., 2011. Effect of age-dependent exposure to lead on hepatotoxicity and nephrotoxicity in male rats. Environ. Toxicol. 26 (1), 68-78.

Brunst, K.J., Ryan, P.H., Lockey, J.E., Bernstein, D.I., McKay, R.T., Khurana Hershey, G. K., Villareal, M., Biagini Myers, J.M., Levin, L., Burkle, J., Evans, S., Lemasters, G.K., 2012. Unraveling the relationship between aeroallergen sensitization, gender, second-hand smoke exposure, and impaired lung function. Pediatr. Allergy Immunol. 23 (5), 479-487.

Brzóska, M.M., 2012. Low-level chronic exposure to cadmium enhances the risk of long bone fractures: a study on a female rat model of human lifetime exposure. J. Appl. Toxicol. 32 (1), 34-44.

Butz, A.M., Breysse, P., Rand, C., Curtin-Brosnan, J., Eggleston, P., Diette, G.B., Williams, D., Bernert, J.T., Matsui, E.C., 2011. Household smoking behavior: effects on indoor air quality and health of urban children with asthma.Matern. Child Health J. 15 (4), 460-468.

Buzard, G.S., Kasprzak, K.S., 2000. Possible roles of nitric oxide and redox cell signaling in metal-induced toxicity and carcinogenesis: a review. J. Environ. Pathol. Toxicol. Oncol. 19 (3), 179-199.

Byrne, C., Divekar, S.D., Storchan, G.B., Parodi, D.A., Martin, M.B., 2013. Metals and breast cancer. J. Mammary Gland Biol. Neoplasia 18, 63-73.

Calphor, S.C., Huribal, M., Marsan, B.U., Ricotta, J.J., Dryski, M., 1997. Nicotine and its metabolit cotinine are mitogenic for human vascular smooth muscle cells. J. Vasc. Surg. 25 (4), 682-688.

Cerna, M., Krskova, A., Cejchanova, M., Spevackova, V., 2012. Human biomonitoring in the Czech Republic: an overview. Int. J. Hyg. Environ. Health 215 (2), 109-119.

Chang, C., Lee, S.O., Yeh, S., Chang, T.M., 2014. Androgen receptor (AR) differential roles in hormone-related tumors including prostate, bladder, kidney, lung, breast and liver. Oncogene 33 (25), 3225-3234. http://dx.doi.org/10.1038/ onc.2013.274.

Ciesielski, T., Weuve, J., Bellinger, D.C., Schwartz, J., Lanphear, B., Wright, R.O., 2012 Cadmium exposure and neurodevelopmental outcomes in U.S. children. Environ. Health Perspect. 120 (5), 758-763.

Colacino, J.A., Arthur, A.E., Ferguson, K.K., Rozek, L.S., 2014. Dietary antioxidant and anti-inflammatory intake modifies the effect of cadmium exposure on markers of systemic inflammation and oxidative stress. Environ. Res. 131, 6-12.

Courant, F., Aksglaede, L., Antignac, J.P., Monteau, F., Sorensen, K., Andersson, A.M., Skakkebaek, N.E., Juul, A., Bizec, B.L., 2010. Assessment of circulating sex steroid levels in prepubertal and pubertal boys and girls by a novel ultrasensitive gas chromatography-tandem mass spectrometry method. J. Clin. Endocrinol. Metab. 95 (1), 82-92.

Crespo-López, M.E., Macêdo, G.L., Pereira, S.I., Arrifano, G.P., Picanço-Diniz, D.L., do Nascimento, J.L., Herculano, A.M., 2009. Mercury and human genotoxicity: critical considerations and possible molecular mechanisms. Pharmacol. Res. 60 (4), 212-220.

Darbre, P.D., 2006. Metalloestrogens: an emerging class of inorganic xenoestrogens with potential to add to the oestrogenic burden of the human breast. J. Appl. Toxicol. 26 (3), 191-197.

Ferrara, P.M., Costanzi, S., Naticchia, A., Sturniolo, A., Gambaro, G., 2010. Low level exposure to cadmium increases the risk of chronic kidney disease: analysis of the NHANES 1999-2006. BMC Public Health 10, 304.

Fucic, A., Gamulin, M., Ferencic, Z., Katic, J., Krayer von Krauss, M., Bartonova, A., Merlo, D.F., 2012. Environmental exposure to xenoestrogens and oestrogen related cancers: reproductive system, breast, lung, kidney, pancreas, and brain. Environ. Health 2811 (Suppl. 1), S8.

Fucic, A., Gamulin, M., Ferencic, Z., Rokotov, D.S., Katic, J., Bartonova, A., Lovasic, I.B., Merlo, D.F., 2010. Lung cancer and environmental chemical exposure: a review of our current state of knowledge with reference to the role of hormones and hormone receptors as an increased risk factor for developing lung cancer in man. Toxicol. Pathol. 38 (6), 849-855.

Furman, D., Hejblumb, B.P., Jojic, S.N., Dekker, V., Rodolphe Thiébaut, Tibshirani, Robert J., Davis, Mark M., 2013. Systems analysis of sex differenc es reveals an immunosuppressive role for testosterone in the response to influenza vaccination, 2013

Giannandrea, F., Paoli, D., Figà-Talamanca, I., Lombardo, F., Lenzi, A., Gandini, L. 2013. Effect of endogenous and exogenous hormones on testicular cancer: the epidemiological evidence. Int. J. Dev. Biol. 57 (2-4), 255-263.

Golub, M.S., Collman, G.W., Foster, P.M., Kimmel, C.A., Rajpert-De Meyts, E., Reiter, E. O., Sharpe, R.M., Skakkebaek, N.E., Toppari, J., 2008. Public health implications of altered puberty timing. Pediatrics 121 (Suppl. 3), S218-S230. 
Hagenfeldt, Y., Eriksson, H.A., 1988. The estrogen receptor in the rat kidney. Ontogeny, properties and effects of gonadectomy on its concentration. J. Steroid Biochem. 31 (1), 49-56.

Horton, L.M., Mortensen, M.E., Iossifova, Y., Wald, M.M., Burgess, P., 2013. What do we know of childhood exposures to metals (arsenic, cadmium, lead, and mercury) in emerging market countries? Int. J. Pediatr. 2013, 872596.

Hukkanen, J., Jacob 3rd, P., Benowitz, N.L., 2005. Metabolism and disposition kinetics of nicotine. Pharmacol. Rev. 57 (1), 79-115.

Hwang, S.H., Hwang, J.H., Moon, J.S., Lee, D.H., 2012. Environmental tobacco smoke and children's health. Korean J. Pediatr. 55 (2), 35-41.

Jacobson-Dicman, E., Lee, M.M., 2009. The influence of endocrine disruptors on pubertal timing. Curr. Opin. Endocrinol. Diabetes Obes. 16 (1), 25-30.

Iwata, K., Saito, H., Moryama, M., Nakano, A., 1993. Renal tubular function after reduction of environmental cadmium exposure: a ten-year follow-up. Arch. Environ. Health 48 (3), 157-163.

Kadohama, N., Shintani, K., Osawa, Y., 1993. Tobacco alkaloid derivatives as inhibitors of breast cancer aromatase. Cancer Lett. 75, 175-182.

Kalra, R., Singh, S.P., Pena-Philippides, J.C., Langley, R.J., Razani-Boroujerdi, S., Sopori, M.L., 2004. Immunosuppressive and anti-inflammatory effects of nicotine administered by patch in an animal model. Clin. Diagn. Lab. Immunol. 3, 563-568.

Kido, T., Shaikh, Z.A., Kito, H., Honda, R., Nogawa, K., 1991. Dose-response relationship between urinary cadmium and metallothionein in a Japanese population environmentally exposed to cadmium. Toxicology 65 (3), 325-332.

Kim, K.H., Lee, C.M., Park, S.M., Cho, B., Chang, Y., Park, S.G., Lee, K., 2013. Secondhand smoke exposure and osteoporosis in never-smoking postmenopausal women:the Fourth Korea National Health and Nutrition Examination Survey. Osteoporo. Int. 24 (2), 523-532.

Kippler, M., Tofail, F., Hamadani, J.D., Gardner, R.M., Grantham-McGregor, S.M., Bottai, M., Vahter, M., 2012. Early-life cadmium exposure and child development in 5-year-old girls and boys: a cohort study in rural Bangladesh. Environ. Health Perspect. 120 (10), 1462-1468.

Klaassen, C.D., Liu, J., Diwan, B.A., 2009. Metallothionein protection of cadmium toxicity Toxicol Appl. Pharmacol 238 (3), 215-220.

Kobayashi, E., Suwazono, Y., Honda, R., Dochi, M., Nishijo, M., Kido, T., Nakagawa, H. 2008. Changes in renal tubular and glomerular functions and biological acidbase balance after soil replacement in Cd-polluted rice paddies calculated with general linear mixed model. Biol. Trace Elem. Res. 124 (2), 164-172.

Leong, J.W., Dore, N.D., Shelley, K., Holt, E.J., Laing, I.A., Palmer, L.J., LeSouef, P.N., 1998. The elimination half-life of urinary cotinine in children of tobaccosmoking mothers. Pulm. Pharmacol. Ther. 11 (4), 287-290.

Liu, P., Wang, C.N., Song, X.Y., Wu, Y.N., 2010. Dietary intake of lead and cadmium by children and adults - result calculated from dietary recall and available lead/ cadmium level in food in comparison to result from food duplicate diet method. Int. J. Hyg. Environ. Health 213 (6), 450-457.

Mantovani, A., Fucic, A., 2014. Puberty dysregulation and increased risk of disease in adult life: possible modes of action. Reprod. Toxicol. 44, 15-22, http://dx.doi. org/10.1016/j.reprotox.2013.06.002.

Milnerowicz, H., 1997. Concentration of metals, ceruloplasmin, metallothionein an activity of N-acetyl-beta-D-glucosaminidase and gamma-glutamyltransferase in pregnant women who smoke and in those environmentally exposed to tobacco and in their infants. II. Influence of environmental exposure in the Copper basin. Int. J. Occup. Med. Environ. Health 10 (3), 273-282.

Montano, M., Gutleb, A.C., Murk, A.J., 2013. Persistent toxic burdens of halogenated phenolic compounds in humans and wildlife. Environ. Sci. Technol. 47, 6071-6081.

Myong, J.P., Kim, H.R., Choi, S.E., Koo, J.W., 2013. Dose-related effect of urinary cotinine levels on bone mineral density among Korean females. Osteoporos. Int. 24 (4) 1339-1346.

Nakagawa, H., NIshio, M., 1996. Environmental cadmium exposure, hypertension and cardiovascular risk. J. Cardiovasc. Risk 3, 11-15.

Nasiadek, M., Swiatkowska, E., Nowinska, A., Krawczyk, T., Wilczynski, J.R., Sapota, A., 2011. The effect of cadmium on steroid hormones and their receptors in women with uterine myomas. Arch. Environ. Contam. Toxicol 60 (4), 734-741.

Okitsu, K., Kanda, T., Imazeki, F., Yonemitsu, Y., Ray, R.B., Chang, C., Yokosuka, O., 2010. Involvement of interleukin-6 and androgen receptor signaling in pancreatic cancer. Genes Cancer 1 (8), 859-867.

Robinson, D., Toozs-Hobson, P., Cardozo, L., 2013. The effect of hormones on the lower urinary tract. Menopause Int. 19 (4), 155-162.
Rogol, A.D., Roemmich, J.N., Clark, P., 2002. Growth at puberty. J. Adolesc. Health 31 (6), 192-200.

Ronco, A.M., Arguello, G., Suazo, M., Llanos, M.N., 2005. Increased levels of metallothionein in placenta of smokers. Toxicology 208 (1), 133-139.

Satarug, S., Moore, M., 2004. Adverse health effects of chronic exposure to low-level cadmium in foodstuffs and cigarette smoke. Environ. Health Perspect. 112 (10), 1099-1103.

Schindler, B.K., Esteban, M., Koch, H.M., Castano, A., Koslitz, S., Cañas, A., Casteleyn, L., Kolossa-Gehring, M., Schwedler, G., Schoeters, G., Hond, E.D., Sepai, O., Exley, K., Bloemen, L., Horvat, M., Knudsen, L.E., Joas, A., Joas, R., Biot, P., Aerts, D. Lopez, A., Huetos, O., Katsonouri, A., Maurer-Chronakis, K., Kasparova, L., Vrbík, K., Rudnai, P., Naray, M., Guignard, C., Fischer, M.,E., Ligocka, D., Janasik, B., Reis, M.F., Namorado, S., Pop, C., Dumitrascu, I., Halzlova, K., Fabianova, E., Mazej, D., Tratnik, J.S., Berglund, M., Jönsson, B., Lehmann, A., Crettaz, P., Frederiksen, H., Nielsen, F., McGrath, H., Nesbitt, I., De Cremer, K., Vanermen, G., Koppen, G., Wilhelm, M., Becker, K., Angerer, J., 2013. The European COPHES/DEMOCOPHES project: towards transnational comparability and reliability of human biomonitoring results. Int. J. Hyg. Environ. Health 217, 653-661.

Soldin, O.P., Makambi, K.H., Soldin, S.J., O'Mara, D.M., 2011. Steroid hormone levels associated with passive and active smoking. Steroids 76 (7), 653-659.

Strong, C., Chang, L.Y., 2013. Family socioeconomic status, household tobacco smoke, and asthma attack among children below 12 years of age: gender differences. J. Child Health Care (Epub ahead of print).

Suwazono, Y., Sand, S., Vahter, M., Filipsson, A.F., Skerfving, S., Lidfeldt, J., Akesson, A., 2006. Benchmark dose for cadmium-induced renal effects in humans. Environ. Health Perspect. 114 (7), 1072-1076.

Thike, A.A., Yong-Zheng Chong, L., Cheok, P.Y, Li, H.H., Wai-Cheong Yip, G., Huat Bay, B., Tse, G.M., Iqbal, J., Tan, P.H., 2014. Loss of androgen receptor expression predicts early recurrence in triple-negative and basal-like breast cancer. Mod. Pathol. 27 (3), 352-360.

Toppari, J., Juul, A., 2010. Trends in puberty timing in humans and environmental modifiers. Mol. Cell Endocrinol. 324 (1-2), 39-44.

Trzcinka-Ochocka, M., Jakubowski, M., Razniewska, G., Halatek, T., Gazewski, A., 2004. The effects of environmental cadmium exposure on kidney function: the possible influence of age. Environ. Res. 95 (2), 143-150.

Tung, K.Y., Wu, K.Y., Tsai, C.H., Su, M.W., Chen, C.H., Lin, M.H., Chen, Y.C., Wu, W.C., Lee, Y.L., 2013. Association of time-location patterns with urinary cotinine among asthmatic children under household environmental tobacco smoke exposure. Environ. Res. 124, 7-12.

Veldhuis, J.D., Pincus, S.M., Mitamura, R., Yano, K., Suzuki, N., Ito, Y., Makita, Y., Okuno, A., 2001. Developmentally delimited emergence of more orderly luteinizing hormone and testosterone secretion during late prepuberty in boys. J. Clin. Endocrinol. Metab. 86 (1), 80-89.

Yakimchuk, K., Norin, S., Kimby, E., Hägglund, H., Warner, M., Gustafsson, J.Å, 2012. Up-regulated estrogen receptor $\beta 2$ in chronic lymphocytic leukemia. Leuk. Lymphoma 53 (1), 139-144.

Yolton, K., Dietrich, K., Auinger, P., Lanphear, B.P., Hornung, R., 2005. Exposure to environmental tobacco smoke and cognitive abilities among U.S. children and adolescents. Environ. Health Perspect. 113 (1), 98-103.

Watanabe, T., Nakatsuka, H., Shimbo, S., Yaginuma-Sakurai, K., Ikeda, M., 2013. High cadmium and low lead exposure of children in Japan. Int. Arch. Occup. Environ. Health 86 (8), 865-873.

Zeller, W.J., Berger, M.R., 1989. Nicotine and estrogen metabolism - possible implications of smoking for growth and outcome of treatment of hormone-dependent cancer? Discussion of experimental results. J. Cancer Res. Clin. Oncol. 115 (6), 601-603.

Zhang, W., Pang, F., Huang, Y., Yan, P., Lin, W., 2008. Cadmium exerts toxic effects on ovarian steroid hormone release in rats. Toxicol. Lett. 182, 18-23.

Zhao, Q., Wang, Y., Cao, Y., Chen, A., Ren, M., Ge, Y., Yu, Z., Wan, S., Hu, A., Bo, Q. Ruan, L., Chen, H., Qin, S., Chen, W., Hu, C., Tao, F., Xu, D., Xu, J., Wen, L., Li, L., 2014. Potential health risks of heavy metals in cultivated topsoil and grain, including correlations with human primary liver, lung and gastric cancer, in Anhui province, Eastern China. Sci. Total Environ. 1, 340-347.

Znaor, A., Lortet-Tieulent, J., Jemal, A., Bray, F., 2013. International variations and trends in testicular cancer incidence and mortality. Eur. Urol. S0302-2838 (13), 01201-01203. 